\title{
Middle School Student Behavior In The Utilization Of Electronic Books *)
}

BY:

\author{
E. Oos M. Anwas (1), JakaWarsihna (2), IrfanaSteviano (3) \\ (1) dan (2) Center for Curriculum and Books, Research and Development \\ Agency, Ministry of Education \& Culture. \\ (3) ICT Center for Education, Ministry of Education \& Culture.
}

\section{(1) oos.anwas@kemdikbud.go.id \\ (2) jaka.warsihna@kemdikbud.go.id}

(3) irfana@kemdikbud.go.id

\begin{abstract}
Center for Curriculum and Books Ministry of Education and Culture has launched electronic books through web portal http://buku.kemdikbud.go.id/ The book were still based on text and images (the first generation electronic books) however has helped teachers and students in learning. Since then electronic books began to be developed by publishers, communities, and other institutions. The fast growing use of Internetamong students hasturned the electronic books into an alternative of quality learning resources. This study aims to determine the behavior of junior high school students in the use of electronic books. Survey conducted in the cities of Jakarta, Bandung, Jogjakarta, Denpasar, and Banda Aceh, stated that the intensity of the use of electronic books by junior high school students is known to almost half (47\%) already using electronic books. From the study reveals that the demands of students in the development of electronic books are not only based on text and images, but also based on video/animation, audio, simulation, and augmented reality. The results of the Spearman correlation test shown that the factors that affect the intensity of the use of electronic books are students' attitudes toward electronic books, the intensity of the teacher's lesson assignments, self motivation to use electronic books, encouragement from schoolmates, and the level of parental education in this case is the mother. Therefore, electronic books especially those developed by the government need to be continuously improved in accordance with the demands of students and optimize the characteristics of electronic books. On the other hand, socialization about electronics books especially for teachers, students, and parents is very important also.
\end{abstract}

Key words: Electronic books, Internet, junior high school students'

behavior towards electronic books, Internet

*) This article is part of the results of the research on the Development of Interactive Electronic Books that are funded by the Center for Curriculum and Books in 2018. 


\section{PRELIMINARY}

The development of information technology and communication has significantly affected various aspects of life, including the behavior of students in learning. Many studies show that students have used ICT in learning ( Tuapawa, Kimberley , 2017 ; Rui, 2017; Penjor and Zander , 2016 ; Shaibou , 2017 ). The influence of ICT on learning also affects the textbooks. In reality in school, textbook lessons become the main learning resource for students and teachers. The book was designed in accordance with the applicable curriculum (Curriculum 2013). Implementation of 2013 Curriculum needs ICT support (Anwas, 2013), especially electronic books. The Center for Curriculum and Books, the Research and Development Agency, the Ministry of Education and Culture of the Republic of Indonesia has developed textbooks that are in accordance with the curriculum.

The development of textbooks is made in conventional format (print) and electronic (digital) format. Electronics formats have been uploaded via buku.kemdikbud.go.id page.Through this page, students, teachers, parents, and the community can use it for free. They can access, read, download, or print it. For those who are interested in printing and used for business purposes (trade), it can be done by referring to the highest retail price (HET) set by the government.

The electronically developed book, although still based on text and images (first generation digital books), has helped teachers and students in learning. Electronic books are also being developed by the publisher, society, andother institutions. Along with the development of the use of the internet, including among students, the use of electronic books has become an alternative variety of quality learning resources. Through the development of conventional and electronic books, it is expected to be able to create a quality, inexpensive and evenly distributed book according to the demands of Law Number 3 of 2018 concerning the Books System.

Reality, the reading culture of Indonesia is still relatif low. Based on data from the National Library in 2017, the average frequency of reading for Indonesians is only three to four times per week, while the number of books read is on average only five to nine books per year (CNN Indonesia, 2018). The results of Bakar's research (2014) show that one of the factors causing low interest in reading books is the ease of access to information through internet media from mobile phones and computers, making it easier for people to find information and knowledge. On the other hand, Indonesians now prefer to interact with their devices rather than reading books, watching television, listening to radio, and other information exchange activities that are conventional in nature. Theoriginal research of Siregar (2014), that internet use is higher than the use of textbooks in completing student lecture assignments. Likewise on among children and adolescents, research Chalim and Anwas (2018) showed that the students used it when doing homework (PR) from the teacher, that is almost entirely (95\%) use the Internet, and only $70 \%$ are using a book. Therefore, the migration of conventional books to digital books is expected to increase the culture of reading interest. 
Many electronic books (digital) have also been developed by publishers (private). Electronic book models also continue to develop according to the demands of the times. The electronic book model has now entered the fourth generation. The first generation electronic book model, is a simple model. Material is presented digitally in the form of text and images. The electronic book developed by Puskurbuk is still classified as the first generation. Second-generation electronic books, already equipped with shapes audio, video / information, and simulation. The third generation, equipped with links (links) in the form of hypertext, hyperlink, or hypermedia. The fourth-generation model of the electronic book, is equipped with interactive and presentation of content in the form augmented reality.

The diversity of models and forms of electronic books is interesting to study the development of electronic textbooks in accordance with the conditions of the country Indonesia that is rich in diversity. Electronic books are not just text and images (Anwas, 2016). Therefore the Center for Curriculum and Books in 2018 conducts in-depth research on the Interactive Electronic Book Model which is in accordance with the conditions of Indonesia. In this paper one of the results of a preliminary study is presented from the activity or research. The results of this preliminary study is focus at the student's behavior toward electronic books. Therefore the research in this paper aims to find out : 1) the behavior of junior high school students in the use of electronic books ; and 2) factors that relate to the intensity of use in the electronic book.

\section{METHOD}

This study is part of research development model Interactive Electronic Book sponsored by the Center for Curriculum and Perbukuan, the Research and Development of the Ministry of Education and Culture in 2018. The study used methods of research and development. This method is useful for developing, perfecting, and validating certain products in various fields, such as education and teaching (Borg \& Gall , 1979). In detail Borg and Gall (1979) there are ten steps activity of research and development methods

(research and development). One step in this stage is the preliminary research. This

paper is a preliminary study of the research on the Development of

Interactive Electronic Book Models sponsored by the Central for Curriculum and Books. The method in this preliminary study was carried out through a survey. The location of the study as a population was carried out on State Junior High School students in four cities, namely Jakarta (DKI Jakarta), Bandung (West Java), Jogjakarta IN Jogjakarta), Denpasar (Bali), and Banda Aceh (IN Aceh) . Samples were taken randomly, namely at SMPN 3 Denpasar, province of Bali, SMPN

1Yoyakarta, SMPN 2 Bandung, West Java, SMP 3 Banda Aceh, and 49th Kramatjati Middle School in East Jakarta. Data was collected through questionnaire and in-depth interviews. Data collection in this field was carried out in September 2018. Data analysis techniques used descriptive statistics and correlation tests with the help of SPSS version 24 . 


\section{RESULTS AND DISCUSSION}

The behavior of the students in the use of electronic books is measured from the aspect students experiences to electronic books. The respondents data in this study were 534 students (Table 1), it turns out that less than half (47\%) stated that they had used electronic books. More than half of the respondents $(53 \%)$ stated that they had never used it.

Table -1

Students Users of electronic books

\begin{tabular}{|c|l|c|c|}
\hline No. & \multicolumn{1}{|c|}{ Using BE } & total & $\%$ \\
\hline 1 & Have Used & 251 & 47 \\
\hline 2 & Never Used & 283 & 53 \\
\hline & total & 534 & 100 \\
\hline
\end{tabular}

The results of the deepening through interviews with students, the reasons for not using electronic books are quite diverse. These reasons, among others: their ignorance of electronic books, do not have electronic books, and did not understand how to access / download electronic books. There are also because of their lack of understanding about electronic books, those who are concerned prefer the printed version. But after it was explained that electronic books could present multimedia content, students explicitly changed their opinions, stating that they preferred electronic books. Another reason is technical, among others: not provided by the schools, schools do not connect to the internet, minimal internet quota, and not a mandatory in school. All the reasons which is the reason not utilize electronic book. Electronic books have many advantages, while printed books have many obstacles in terms of cost and efficacy in learning ( Hamedi and Ezaleila, 2015 ) .

Table -2

Source of Electronic Books

\begin{tabular}{|c|l|c|c|}
\hline No. & \multicolumn{1}{|c|}{$\begin{array}{c}\text { Source of Electronic } \\
\text { Books }\end{array}$} & total & $\%$ \\
\hline 1 & Internet & 210 & 83,7 \\
\hline 2 & Teacher & 78 & 31.1 \\
\hline 3 & Friend & 58 & 23,1 \\
\hline 4 & Parents & 23 & 9.2 \\
\hline
\end{tabular}

Furthermore, the behavior of using electronic books is explored towards students who have used electronic books. Conversely, students who have never used an electronic book were not included in the data. Table 2 , describes the source of electronic books that students have used. Almost all respondents 
(83.7\%) stated that electronic books obtain from the internet. Only under $50 \%$ of the source of the electronic book is obtained from the teacher, friend, and parents. Table 1 and Table 2 indicate that electronic books are still not popular among students and thecommunity.

Table - 3

Place to Use Electronic Books

\begin{tabular}{|c|l|c|c|}
\hline No. & The place & total & $\%$ \\
\hline 1 & House & 203 & 80.9 \\
\hline 2 & School & 128 & 51.0 \\
\hline 3 & Cafe & 26 & 10.4 \\
\hline 4 & Library & 17 & 6.8 \\
\hline 5 & Public facilities & 17 & 6.8 \\
\hline
\end{tabular}

Students' behavior, especially in relation to the place in using electronic books, is presented in Table 3. The place to use electronic books is mostly done at home $(80.9 \%)$. This data is related to Table 2, that they use electronic books from the internet. The use of the internet is mostly done in his house, so using electronic books is more widely used at home. Indeed, internet usage in schools is still limited. There are also schools that prohibit students from carrying and using smart phone at school. The use of electronic books in schools is also more than half (51.0). The use of electronic books in this school is done when getting assignments from the teacher or during leisure time outside of learning. In other places, such as libraries, internet cafes, and public facilities are still very small .

Table - 4

Electronic Book Devices

\begin{tabular}{|c|l|c|c|}
\hline No. & PC device & total & $\%$ \\
\hline 1 & Smartphone & 218 & 86.9 \\
\hline 2 & Laptop & 76 & 30.3 \\
\hline 3 & PC & 22 & 8.8 \\
\hline 4 & Tablet & 11 & 4.4 \\
\hline
\end{tabular}

Devices in using electronic books used by respondents in Table 4 , show that most are smartphones. Only a small percentage of students use laptops, especially PCs. The use of Smar tphone is related to the ease and practicality of its use. Therefore, the development of electronic books need to be designed that are easily accessible by utilizing smartphone (android technology). 
Table - 5

Reasons for using Electronic Books

\begin{tabular}{|c|l|c|c|}
\hline No. & Electronic Books Needs & total & $\%$ \\
\hline 1 & School assignment & 179 & 71.3 \\
\hline 2 & Own initiative & 145 & 57.8 \\
\hline 3 & Parental encouragement & 17 & 6.8 \\
\hline 4 & Encouragement of friends & 15 & 6.0 \\
\hline
\end{tabular}

Table 5 , shows that the reasons for using electronic books are mostly doing assignments from school (71.3\%). This means that electronic books are important for them in supporting the learning process in school. The second most reason for using electronic books is its own initiative, especially in finding various things including developing hobbies and entertainment for generations in the present. The data also pointed to an optimism, that if the electronic book developed more optimal (using multimedia and interactive) it is expected to facilitate and attract students, as a motivation for them to develop their talents and interest in the millennial generation today.

Table - 6

Frequency of using Electronic Books

\begin{tabular}{|c|l|c|c|}
\hline No. & & total & $\%$ \\
\hline 1 & Very rarely & 14 & 5.6 \\
\hline 2 & Rarely & 115 & 45.8 \\
\hline 3 & Often & 109 & 43.4 \\
\hline 4 & Very often & 13 & 5.2 \\
\hline
\end{tabular}

The frequency of using electronic books among middle school students who have used them in sufficient categories. Respondents who stated often nearly 50 percent. It is still not good to use electronic books, presumably because electronic books that have been developed at this time are still the first generation , which is only based on text and images, so that it is not attractive to students. As a result of deepening with students, they were very interested if the book was developed in a multimedia format, presenting text, image, audio, video, animation, simulation and other interactive features. 
Table- 7

Able to Use Electronic Books

\begin{tabular}{|c|c|c|c|}
\hline No. & Skill to use EB & total & $\%$ \\
\hline 1 & Very difficult & 4 & 1.6 \\
\hline 2 & Difficult & 14 & 5.6 \\
\hline 3 & Is being & 199 & 79.3 \\
\hline 4 & Easy & 34 & 13.5 \\
\hline
\end{tabular}

Students' ability to use electronic books is undoubted. Table 7 refers that the students who have tried electronic book states entirely easy. This is in line with the characteristics of today's children who are so familiar with various digital devices and applications. The development of electronic books, providing optimism for junior high school students, they are relativelyeasy to operate.

The results of the Spearman correlation test show that factors related to student intensity in the use of electronic books are presented in Table 8. These results statistically show that: 1) student attitudes toward electronic books; 2) the intensity of the lesson assignments from the teacher; 3) students 'self-interest in using electronic books, and 4) encouragement from their schoolmates is significantly and positively related to the confidence level of $99 \%$ with students' intensity in using electronic books.

Table 8

The factors that relate with the intensity of use of Electronic Books

\begin{tabular}{|l|l|c|c|}
\hline No. & \multicolumn{1}{|c|}{ Variable } & $\mathrm{r}$ & $\mathrm{sig}$ \\
\hline & $\begin{array}{l}\text { Attitude towards } \\
\text { electronic books }\end{array}$ & .941 & $.000^{* *}$ \\
\hline & $\begin{array}{l}\text { Task intensity of the } \\
\text { teacher }\end{array}$ & .720 & $.000^{* *}$ \\
\hline & Self-desire & .675 & $.000^{* *}$ \\
\hline $\begin{array}{l}\text { Encouragement from } \\
\text { schoolmates }\end{array}$ & .197 & $.000^{* *}$ \\
\hline
\end{tabular}

This is meaning if students 'attitudes toward electronic books, the intensity of the lesson assignments from teachers, students' self-interest in using electronic books, and the encouragement of their schoolmates increases, the intensity of using electronic books also increases. Conversely, if students 'attitudes toward electronic books, the intensity of learning assignments from teachers, students' self-interest in using electronic books, and the encouragement of their schoolmates is low, then the intensity uses electronics books lowas well.

To increase the variables related to the intensity of the use of electronic books, the quality of the electronic book needs to be improved. Electronic books, 
especially textbooks that are currently being developed are based on text and images only. In other words the electronic book is still in the category of first generation electronic books. Now a fourth generation electronic book has developed . This latest generation of electronic books, content presentation is not only based on text and images, but is equipped with audio, video, animation, simulation, even augmented reality. Likewise electronic books of the present generation need to be equipped with other features that are interactive and make it easier for students to learn.

Electronic books have many advantages. Malaysia has been exploring and developing electronic books since 2014, although many stakeholders in the field of education such as teachers, students, parents, publishers, and others include infrastructure that was not yet ready ( Hamedi and Ezaleila, 2015 ). Indonesia has also begun to develop the electronic books. Now is the time for more improvement. Ministry of Education and Culture The Republic of Indonesia is now developing electronic books, especially textbooks, by optimizing the sophistication of electronic technology according to the demands of the millennial generation.

\section{CONCLUSIONS AND RECOMMENDATIONS}

In general, the behavior of students in the use of electronic books is relatively good, even though students who have used electronic books are still less than half. The reasons for students who have not used electronic books include: ignorance of electronic books, not having electronic books, and not understand how to access I use electronic books. Based on data from students who have used electronic books, note that: intesity use is in fair category, most access it from the Internet, most access it at home, device may most used are by smartphones, mostly used to do school assignments, and almost all students who have used electronic books say they are capable and easy.

Student's intensity in using electronic books is significantly and positively related to students 'attitudes toward electronic books, intensity of lesson assignments from teachers, students' self- interest in using electronic books, and encouragement from their schoolmates . if students' attitudes toward electronic books, the intensity of the tasks of the lessons of the teacher, the student desires to use electronic books, as well as the encouragement of school friends increases, the intensity of use of electronic books increase. Instead, these variables declines, the intensity using electronic books correspondingly reduced.

To improve students 'attitudes towards electronic books, the intensity of teaching assignments from teachers, students' self - interest in using electronic books, and encouragement from their schoolmates, the quality of their electronic books needs to be improved. Electronic books, need to be developed not only based on text and images, but need audio, video, animation, simulation, and augmented reality according to the material demands and characteristics of the media. Electronic books of the present generation also need to be equipped with other interactive features and make it easier for students to learn. Therefore the 
government (Ministry of Education and Culture) and the private sector need to immediately develop various electronic book models that optimize the characteristics of electronic books and according to the demands of the millennial generation. Furthermore, the results of the development of quality electronic books , need to be disseminated to the community in stages and continuously, especially to students, teachers and parents in improving the quality of learning according to the demands of millennial independence.

\section{BIBLIOGRAPHY}

Anwas, Oos M. 2016. Information and Communication Technology Based Textbook Model, Kwangsan Journal. Vol 4 Number 1 June 2016. Surabaya BPMTPK.

Anwas, Oos M. 2013. The role of ICT in the Implementation of the 2013 Curriculum. Teknodik Journal Vol. 17 No. 1, March 2013, Jakarta: Pustekkom Kemdikbud.

Bakar, SAB 2014. Factors Causing Low Reading Interest in the Community in the Community Reading Park (Case Study in the Cinta Baca Community Reading Park, Lempuing Village, Ratu Agung Sub-District, Bengkulu City). Thesis, University of Bengkulu.

Borg, R. \& Gall. (1979). Educational Research; An introduction, New: Long Man

Chalim, Saifuddin and Anwas, Oos M. 2018. The Role of Parents and Teachers in Building the Internet as Learning Resources. Extension Journal, Postgraduate Program of IPB. March 2018 Vol.14 No. 1. pp. 42 52. http://jurnal.ipb.ac.id/index.php/jupe/article/view/19558 .

CNN Indonesia. 2018. Indonesia's Reading Interests Are Still Low. Accessed on July 14, 2018 from: https://www.cnnindonesia.com/gayahidup/20180326160959-282-285982/minat-baca-masyarakat-indonesia$\underline{\text { masih-rendah }}$

Darlen, RF, Sjarkawi, Lukman, A. 2015. Development of Interactive E-Book for Middle School Physics Learning. Tekno-Pedagogi Journal, 5 (1), p. 13-23.

Hamedi, MA, Ezaleila, BC 2015. Digital Textbook Program in Malaysia: Lessons from South Korea, Department of Media Studies, Faculty of Arts and Social Sciences, University of Malaya, 50603 Kuala Lumpur, Malaysia. DOI 10.1007 / s12109-015-9425-4 . 
Indonesian Publishers Association (IKAPI). 2018. Indonesian Books Data. Accessed on July 14, 2018 from: http://ikapi.org/2018/01/25/data-perbukuanindonesia/

John, B., Thavavel, V., Jayaraj, J., Muthukumar, A. , Jeevanandam , PK 2016. Design of Open Social Learning Content that Increases Learning Efficiency and Engagement Based on Open Pedagogy. TOJET: The Turkish Online Journal of Educational Technology, 15 (1 ), p . 20-32.

Penjor, Sonam and Zander, Pär-Ola. 2016. Predicting Virtual Learning Environment Adoption: A Case Study. TOJET: The Turkish Online Journal of Educational Technology. January 2016, volume 15 issue 1.

Tuapawa, Kimberley. 2017. Interpreting experiences of students using educational online technologies to interact with teachers in blended tertiary environments: A phenomenological study.Australasian Journal of Educational Technology, 2017, 33 (1).

Rui-Ting Huang, Tzy-Wen Tang, Yi Ping Lee. 2017. Does proactive personality matter in mobile learning? Australasian Journal of Educational Technology, 2017, 33 (2).

Shaibou Abdoulai Haji, Gracemary Eloheneke Moluayonge, Innwoo Park. 2017. Teachers' Use of Information and Communications Technology in Education: Cameroon Secondary Schools Perspectives. TOJET: The Turkish Online Journal of Educational Technology - July 2017, volume 16 issue 3.

Siregar, VM 2014. Comparative Study of Internet Use and Textbooks as a Reference for Tasks. FISIP Thesis at Lampung University.

Law Number 3 of 2018 concerning the Books System. 